\title{
Ammatillisen erityisopetuksen näköaloja
}

\author{
MAIJAHIRVONEN JASAARA KOTAMÄKI
}

A ovat ajankohtaistuneet, vaikkakin erityisopetusta on järjestetty pitkään. Varsinainen ammatillinen erityisopetus Suomessa alkoi erillisissä oppilaitoksissa, joista esimerkkinä on vuonna 1892 perustettu Työkoti sokeille naisille ja vuosisadan vaihteessa myös miehille.

Muita eri kohderyhmille tarkoitettuja oppilaitoksia syntyi seuraavien vuosikymmenten aikana useita. Kuulovammaisten ammattiopetus käynnistyi vuonna 1905 tyttöjen talouskoulussa Pieksämäellä. Se muuttui vuonna 1984 kuulovammaisten ammattikouluksi ja toimii nykyisin Bovallius-opistona. Turun kuulovammaisten ammattikoulu aloitti toimintansa vuonna 1948. Kehitysvammaisten ammatillinen opetus alkoi Perttulan oppilaitoksessa vuonna 1891. Vuonna 1927 tyttökodiksi perustetussa Kuhankosken erityisammattikoulussa käynnistettiin "heikkolahjaisten tyttöjen" ammatillinen koulutus vuonna 1974. Alavudella alkoi vuonna 1952 tyttöjen koulutus, joka muuttui kurssimuotoiseksi ammattikoulutukseksi vuonna 1974. (Mänty 2000, 89.)

Toinen maailmansota oli käännekohta ammatillisen erityisopetuksen kehittymisessä sekä asenteellisesti että käytännössä. Kun vammaisten koulutus oli perustunut segregaatioon, sodan jälkeen vammautuneiden suuri joukko velvoitti yhteiskunnan ottamaan laajempaa vastuuta heidän kouluttamisestaan. Oli tarpeellista kehittää ammatillista kuntoutusta, ja vuonna 1940 perustettu Invalidisäätiö alkoi kehittää koulutustoimintaa. Näissä invalideille tarkoitetuissa oppilaitoksissa oli alkuvuosien oppilaina pääasiassa sodan vammauttamia henkilöitä ja heidän omaisiaan, mutta vähitellen myös muita liikuntavammaisia. Vuonna 1946 säädettiin invaliidihuoltolaki, johon sisällytettiin lääkintä- ja työhuolto sekä koulutus. Sotien jälkeen alettiin siis systemaattisemmin kiinnittää huomiota vammaisten ammatilliseen koulutukseen. Heitä ohjattiin pääosin erillisiin ammattioppilaitoksiin, joissa vammaisten oppilaiden tarvitsema erityinen tuki mahdollistui. Heille tarkoitettuja oppilaitoksia valtiollistettiin ja näin toiminta systematisoitui.

Näistä aluksi erillisistä oppilaitoksista kehittyivät nykyiset ammatilliset erityisoppilaitokset, joita valtion lisäksi ylläpitää 12 yhteisöt ja säätiöt eri puolella Suomea. Ne järjestävät ammatillisen peruskoulutuksen lisäksi valmentavaa ja kuntouttavaa opetusta ja ohjausta. Monet toimivat myös erityisopetuksen palvelu- ja kehittämiskeskuksina.

\section{Ammatillinen erityisopetus laajenee}

$\mathrm{V}$ uonna 1971 annettiin laki ja asetus kuulovammaisten ja näkövammaisten ammattikouluista, joka sääteli valtion ylläpitämään yhtä kuulovammaisten ja yhtä näkövammaisten ammattikoulua. Ammatilliseksi erityisopetukseksi nimettiin tässä vaiheessa vain näissä annettava opetus. Ammatillisen erityisopetuksen komitean (Kom. 1973) työn seurauksena kehittämisen painopiste siirtyi ammatillisiin oppilaitoksiin, joissa ns. apukoululaisille avattiin uusia väyliä perustamalla työvaltaisia erityislinjoja. Näihin aikoihin alettiin puhua ammatillisesta erityisopetuksesta omana käsitteenään. (Klemelä 1999, 278-281.)

Keskiasteen koulunuudistus 1980-luvulla muutti erityisopetuksen käsitettä. Ammatillisen koulutuksen rakennemuutos, oppisisältöjen tavoitetason nostaminen, sisällöllisen painotuksen muuttaminen yleisen jatko-opintokelpoisuuden saavuttamiseksi ja koko ikäluokan kouluttaminen saivat aikaan erityisen tuen lisääntyvän tarpeen.

Ammatillisen koulutuksen kokonaismerkitys oli muuttunut. Samoin erityisopetuksen painopiste muuttui. Haasteena oli siirtyä erillisistä erityisopetuspalveluista ammatillisten oppilaitosten erityisopetuksen yhtenäiseen suunnitteluun. 


\section{Ammattikoulusta avoimiin oppimisympäristöihin}

Ammatillisen koulutuksen rakenne on muuttunut keskiasteen uudistamisen myötä. Myös oppimiskulttuuri uudistui. Volanen $(1997,2004) \mathrm{ni}$ meää tämän palvelukouluksi, jolle on ominaista joustavat koulutusrakenteet, valinnaisuuden lisääntyminen ja opintojen yhdistäminen toisella asteella. Palvelukoulu perustuu yksilöllisyyden ajatukseen. Opiskelija on asiakas, joka valitsee tarjonnasta tarkoituksenmukaisimmat vaihtoehdot. Palvelukoulun johtoajatus opintojen yksilöllistämisestä luo mahdollisuuksia myös erityisopetukselle, etenkin tilanteissa, joissa koulumuotoinen teoriaopetus ei onnistu. Käytännössä kuitenkin opiskelu palvelukoulutyyppisessä ammatillisessa oppilaitoksessa on erilaista kuin perinteisessä ammattikoulussa. Se edellyttää opiskelijalta itseohjautuvuutta, tavoitteisuutta ja valintojen tekemistä, jotka kaikki saattavat tuottaa erityisopiskelijalle vaikeuksia. Erityisopetuksen ja opintojen ohjauksen tarkoituksena on tukea ammatillisen koulutuksen perustehtäviä ja mahdollistaa erityisopiskelijalle opintojen eteneminen ja tutkinnon suorittaminen.

Ammatillisen erityisopetuksen suunnan ja tavoitteiden säätely on ollut moniportaista. Viimeisin opetusministeriön koulutuksen ja tutkimuksen kehittämisohjelma vuosille 2003-2008 asettaa ammatilliselle koulutukselle laajoja tehtäviä. Koulutuksen avulla pyritään lisäämään yhteiskunnallista osallisuutta kiinnittämällä huomiota erityisen tuen ja ohjauksen järjestämiseen oppilaitoksissa. Vuoden 1998 ammatillisen koulutuksen lainsäädäntö määrittelee erityisopetuksen järjestämisen perusteet. Koulutuksen järjestäjän ja oppilaitosten vastuulla on käytännössä luoda erityisopetuksen asemaa, arvoa ja käytännön toteutusta säätelevät linjaukset.

Systemaattisimmin ammatillista erityisopetusta on kehitetty siis 1990-luvun lopulta lähtien. Yhtenäistä erityisopetuksen järjestämisen mallia ei Suomessa ole. Vaikka kehittämisen valtakunnalliset linjaukset ovat yhtenevät, erityisopetus saa oman värinsä paikallisten olosuhteiden mukaan.

Koulutuksen rakennemuutoksen rinnalla erityisopetuksen tarpeen kasvu on ilmeinen. Perusopetuksen oppilaista 27 prosenttia osallistui vuonna 2003 erityisopetukseen jossakin muodossa (Tilastokeskus 2004). Näyttää siltä, että suuri osa tästä ryhmästä jatkaa opintojaan ammatillisessa koulutuksessa ja erityisesti ne oppilaat, joilla erityisen tuen tarve peruskoulussa oli suurin (Lappalainen 2001).

Erityisopiskelijoita on keskimäärin 10 prosenttia ammatillisten oppilaitosten opiskelijoista (Päivänsalo \& Miettinen 2003,8). Eristuen tarve näyttää myös kasvaneen. Tiedon lisääntyessä erityisopetuksen "diagnostiikka" on kehittynyt hienojakoisemmaksi, palveluja kehitetään ja erityisopetukseen kiinnitetään enemmän huomiota. Huomiotta ei kuitenkaan tulisi jättää yhteiskunnallisten tekijöiden vaikutusta erityisopetuksen kasvuun. Taloudellinen lama, pitkäaikaistyöttömyys ja henkinen pahoinvointi kasvattavat yhä uusia "toiseuden sukupolvia" (Pohjola 1994), joille yhteiskunnallinen eteneminen koulutuksen avulla ei ole merkityksellistä.

Perusopetuksessa erityisopetussiirto edellyttää asiantuntijalausuntoja. Perinteisesti erityisopetusta on järjestetty kohderyhmittäin. Ammatillisessa koulutuksessa kuitenkin opiskeluvaikeuksien määrittely on ongelmallista ja joskus sopimuksenvaraistakin, sillä varsinainen syy on usein peittynyt erilaisten muiden tekijöiden alle. Käyttäytymisen alueen ongelmat, motivoitumattomuus ja yleinen elämän päämäärättömyys haittaavat opiskelua. Kodista irtaantuminen, itsenäistyminen ja nuoruusiän kehityskriisit monimutkaistavat erityisen tuen määrittelyä.

Uuden vuosituhannen vaihteeseen mennessä erityisopetuksen järjestämisen velvoitteet täsmentyivät. Valtakunnallista ohjeistusta edustaa vuonna 2004 ilmestynyt ammatillisen erityisopetuksen toimenpideohjelma, jota edelsi erityisopetuksen strategiatyö. Erityisopetukselle antoi suuntaa myös opetusministeriön koulutuksen ja tutkimuksen kehittämisohjelma (2004), jossa painotetaan ammatillisen koulutuksen syrjäytymistä estävää tehtävää. Koulutuksen luonne on uudella vuosituhannella muuttumassa laajemmaksi: opetuksesta kuntoutuksellisuuteen.

Ammatillisten oppilaitosten erityisopetuksen systematisointi ja sen toteuttaminen oppilaitosten ulkopuolella ovat nykypäivän suuntauksia. Erityisopetukselle avaavat uusia mahdollisuuksia työssäoppiminen, opiskelun projektimuotoisuus, työpajojen hyödyntäminen ja näytöt. Rahoitusperusteiden muutoksen myötä tavoitteena on tukea erityisopiskelijoiden integroitumista ammatillisiin oppilaitoksiin ja samalla turvata erityisoppilaitosten rooli vaikeasti vammaisten 
erityisopetuksen järjestäjänä. 2000-luvulta lähtien ammatillisia oppilaitoksia kehitetään ammattikouluista avoimiksi oppimisympäristöiksi, jossa erilaisille ja eri kulttuuritaustoista tuleville opiskelijoille järjestetään monipuolisia opetusja tukipalveluja. Erityisoppilaitokset kehittyvät resurssi- ja palvelukeskuksiksi. (Ammatillisen koulutuksen...2004.)

Erityisen tuen tarpeen lisääntyminen on kuitenkin aina suhteessa kulloisenkin ajan koulutukselle asetettuihin odotuksiin. Tälle ajalle ominainen formaalin koulutuksen yliarvostus ja koulun rakenteelliset muutokset muuttavat opiskelijan asemaa. Muodollinen koulutus on ainoa tapa edetä yhteiskunnassa, eikä tekemiseen ja käden taitoihin liittyvää koulutusta arvosteta riittävästi. Oppisisältöjen "teoreettisempi" taso asettaa erityistukea tarvitsevan oppijan heikkoon asemaan. Oppilaitosten erityisopetuksen haasteena onkin toimia tässä välimaastossa, koulun virallisten tavoitteiden, koulukulttuurin ja toisaalta erityisopiskelijoiden välillä.

\section{Koulutuksen saatavuus ja opiskeli- jan oikeus yksilöllisiin valintoihin}

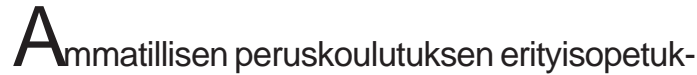
sella pyritään siihen, että kaikilla opiskelijoilla on tasavertaiset koulutus- ja työllistymismahdollisuudet haluamallaan alalla. Koulutusta pyritään kehittämään siten, että erityisopetus on luonnollinen osa yleistä koulutustarjontaa ja käytännön opetustyötä oppilaitoksissa. Koulutuksen tasaarvo edellyttää, että jokaisella Suomessa asuvalla on oppimis- ja toimintaedellytyksistä riippumatta tasavertaiset oikeudet ja mahdollisuudet osallistua koulutukseen.

Opetusministeri Haatainen kirjoittaa "Erityisopetuksen toimenpideohjelman" esipuheessa, että toimenpideohjelman perustana on erityisopetuksen visio, jonka mukaan ammatillinen erityisopetus sekä vammaisten valmentava ja kuntouttava opetus ja ohjaus järjestetään ensisijaisesti ammatillisissa oppilaitoksissa. Tavoitteena on, että tukitoimin ja tarvittaessa opetusta mukauttamalla opiskelija voi osallistua ammatilliseen koulutukseen. Ammatillisten erityisoppilaitosten toiminnan painopisteenä on vaikeimmin vammaisen koulutuksen järjestäminen ja lisäksi niiden tehtävänä on myös huolehtia ammatillisen erityisopetuksen kehittämis-, ohjaus- ja tukitehtävistä yhteistyössä ammatillisten oppilaitosten kanssa. Ministeri kiteyttää ja samalla vetoaa kaikkiin toimijoihin - opetusministeriöön, opetushallitukseen, koulutuksen järjestäjiin ja yhteistyötahoihin: Ammatillisen erityisopetuksen kehittäminen on yhteinen haasteemme. (Ammatillisen erityisopetuksen toimenpideohjelma 2004).

Valtakunnallisen erityisopetuksen vision ja erityisopetuksen toimenpideohjelman mukaan tavoitteena on, että erityistä tukea tarvitsevalla opiskelijalla on perusopetuksen jälkeen mahdollisuus koulutukseen ja ammatilliseen kehittymiseen työtä, työtoimintaa, jatko-opintoja ja hyvää elämää varten. Erityisopetuksen tarjonnan ja sisällön tulee vastata opiskelijan, työelämän ja yhteiskunnan tarpeisiin." (Ammatillisen erityisopetuksen toimenpideohjelma 2004).

Valtakunnallinen erityisopetuksen tarjonta on vielä kapea-alaista. Vuonna 200170 prosenttia erityisopiskelijoista opiskeli tekniikan ja liikenteen alalla $(9,4 \%$ alan opiskelijoista) sekä matkailu-, ravitsemis- ja talousalalla $(10,7 \%$ alan opiskelijoista).

Laaja-alaisen koulutustarjonnan takaamiseksi teimme Jyväskylän ammattiopistossa vuonna 2003 erityisopetuksen toteutuksessa selkeän strategisen linjauksen. Erityisen tuen tarpeessa oleva opiskelija voi hakeutua kaikkiin tutkintoihimme ja meidän tehtävänä on tarjota riittävä tuki opintojen onnistumiselle. Mikäli useita erityisen tuen tarpeessa olevia nuoria hakeutuu suorittamaan saman alan tutkintoa, perustamme tarvittaessa myös pienryhmiä. Lukuvuonna 2004-2005 tällaisia pienryhmiä oli viisi (puu-, kone- ja metalli-, elintarvike-, catering).

Jyväskylän ammattiopistolla on koulutuksen järjestäjänä selkeä näkemys siitä, että opiskelijalla on oikeus hakeutua haluamaansa ammatilliseen tutkintoon. Tämä on suuri muutos totuttuihin toimintatapoihin ja aiheuttaa monia muutospaineita opetuksen järjestelyihin. Se edellyttää myös henkilöstöltä entistä parempaa osaamista ja ammattitaitoa. Ajatus oppimisympäristön esteettömyydestä on helppoa silloin, kun puhutaan fyysisesti esteettömästä oppimisympäristöstä: pyörätuolilla liikkuminen on joustavaa, kuulovammaisella on tarpeelliset apuvälineet ja näkövammaisen liikkuminen ja opiskelun on turvallista. Mutta vaikeampaa on, että päättäjät, henkilöstö ja toiset opiskelijat hyväksyvät erilaiset oppijat yhteisön jäseniksi. Tässä meillä on vielä paljon työtä ja mahdollisuuksia hakea uusia toimintatapoja. 
Erityisopetuksen järjestelyjä Jyväskylän ammattiopistossa

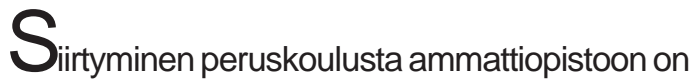

erityistä tukea tarvitsevalle nuorelle iso muutos - jollakin tavalla ensi askel aikuisuuteen. Mitä paremmin pystymme tekemään yhteistyötä perusopetuksen kanssa, sitä helpompaa ja turvallisempaa erityistä tukea tarvitsevan opiskelijan on siirtyä ammattiopintoihin ja sitoutua uusiin haasteisiin. Avainasemassa ovat ammattiopiston opinto-ohjaajat, erityisopettajat ja kuraattorit sekä lähettävän koulun vastaavat toimijat. Nivelvaiheessa tiedonsiirto ja luottamus on kaiken onnistumisen ehto. Valinta tapahtuu luontevimmin yhteishaussa joustavaa hakua käyttäen. Tällöin perusopetuksesta saattaen siirretyt opiskelijat ovat tiedossa jo opintojen alkaessa.

Opintojen alkuvaiheessa luodaan pohja hyvälle erityisopetukselle. Niveltietojen, lähtötasokartoitusten ja luokanvalvojan havaintojen pohjalta määritellään erityisopetuksen mahdollinen tarve. Tuen tarve voidaan havaita myös myöhemmin opintojen kuluessa.

Yksilöllisen tuen takaamiseksi jokaiselle erityistä tukea tarvitsevalle opiskelijalle tehdään henkilökohtainen opetuksen järjestämistä koskeva suunnitelma HOJKS, jossa määritellään erityisopetuksen peruste ja suunnitellaan tukitoimet sekä arvioidaan muut tukitarpeet. HOJKS:n tekemiseen osallistuvat opiskelija, luokanvalvoja, erityisopettaja ja mahdollisesti muitakin tukihenkilöitä sekä alaikäisen nuoren huoltaja. HOJKS on työväline, joka antaa tukea ohjaukseen ja arviointiin sekä lisää suunnitelmallisuutta tukitoimissa. HOJKS:ia päivitetään säännöllisesti. Asiantuntijaryhmä kokoontuu vähintään kerran jokaisessa opintojaksossa seurantatilaisuuteen, jossa jokaisen opiskelijan eteneminen käydään läpi. Seurantatyöllä haluamme varmistua siitä, että opinnot etenevät ja tukitoimia voidaan arvioida systemaattisesti.

Suurin osa erityisopiskelijoista opiskelee integroituna perustutkintoryhmissä. Pienryhmiä perustetaan joustavasti, jos erityistä tukea tarvitsevia opiskelijoita on jollakin alalla useita. Pienryhmän koko on noin kymmenen opiskelijaa. Opiskelija voidaan ohjata pienryhmään myös lukuvuoden aikana tai vastaavasti hän voi siirtyä pienryhmästä tavalliseen perusryhmään. Pienryhmän opetuksesta vastaa ammatillinen erityisopettaja.
Yksilöllisiä vaihtoehtoja opetuksen järjestämisessä ja oppimisen varmistamiseksi on useita: $\mathrm{mm}$. opiskeluajan pidentäminen, opiskelu mukautetuin tavoittein sekä erityiset opetusjärjestelyt. Työtapoina voivat pienryhmäopetuksen lisäksi olla mm. samanaikaisopetus, työvaltainen oppiminen ja työssäoppiminen.

Jokaisella opiskelijalla on oikeus turvalliseen oppimisympäristöön. Ammattiopistossa on päihdestrategia-, kriisi- ja opiskelijahuoltosuunnitelma, jotka sisältävät tavoitteet ja yhtenäiset toimintaohjeet koko ammattiopiston opiskelijoille ja henkilöstölle. Erityisopiskelijalla on vammaislain mukaisesti oikeus kotikuntansa järjestämään tulkkiin, henkilökohtaiseen avustajaan, apuvälineisiin tai muuhun tarvittavan tukeen. Jokaisella opiskelijalla on oikeus Kelan myöntämiin opintososiaalisiin etuihin.

Erityistä tukea tarvitsevien opiskelijoiden opintojen onnistumisesta ja hyvinvoinnista on vastuussa koko henkilöstö. Erityisesti vastuu on opettajilla, luokanvalvojalla, erityisopettajalla, opinto-ohjaajalla, kuraattorilla ja tukipalveluja tuottavalla henkilöstöllä. On keskeistä, että henkilöstö toimii moniammatillisena ryhmänä ja tukee toisiaan. Ammattiopistolla on laaja verkosto alueen muihin toimijoihin - perusopetuksen erityisopettajiin ja opinto-ohjaajiin, sosiaali- ja terveysviranomaisiin, mielenterveyspalveluhenkilöihin. Yhteistyötä tarvitaan myös alueen erityisoppilaitosten, työvoimaviranomaisten, vapaaehtoisjärjestöjen, työssäoppimispaikkojen ja työpajojen kanssa. Tärkeää on pitää tiivistä yhteyttä myös näiden nuorten koteihin.

Elämme erityisopetuksen murrosvaiheessa. Siirtyminen erityisryhmistä integroituun toteutukseen vaatii monipuolista kehitystyötä ja ajattelun ja toiminnan muutoksia kaikilla tasoilla. Siksi olemme käynnistäneet kaksi projektia vuosille 2005-2006. Erityistä tukea tarvitsevien nuorten koulutus- ja uraohjauksen kehittäminen -projektin tavoitteena on ehkäistä syrjäytymistä, kehittää uraohjausta, edistää nuorten sijoittumista työhön ja jatko-opintoihin, rakentaa ammattiopiston erityisopetusverkosto ja lisätä henkilöstön osaamista. Toisen projektin tavoitteena on erityisesti sosiaali- ja terveysalalla sekä tekniikan ja liikenteen alalla kehittää erityistä tukea tarvitsevien opiskelijoiden oppimisympäristöjä. Tässä työssä tärkeä laadun varmistus on osaava ja motivoitunut henkilöstö.

Erityistä tukea tarvitsevat opiskelijat ovat työ- 
yhteisömme jokaisen työntekijän sydämen asia. Menestyvä oppilaitos tunnetaan siitä, että se pitää huolta kaikista oppijoistaan ja saattaa heidät maaliin - ammattilaisiksi, yhteiskuntakelpoisiksi ihmisiksi, "oman elämänsä selviytyjiksi".

\section{Erityisopetuksen kehittämishanke}

rityisopetus ei ole muusta toiminnasta irrallista, vaan sitä toteutetaan koulun sisällä, sen perustehtäviä tukien. Erityisopetuksen tarkasteleminen osana muuttuvia koulutuksen tehtäviä, tavoitteita ja rakennetta voi antaa vastausvaihtoehtoja nykypäivän erityisopetuksen ajankohtaisiin haasteisiin. Koulutukselle asetettujen tavoitteiden ja sen rakenteen muuttuessa myös erityisopetuksen tulisi muuttua.

Jyväskylän ammattiopiston erityisopetuksen kehittämishanke on tutkimus, joka käynnistyi jo vuonna 2001 seudun ammatillisten erityisopettajien verkoston perustamisena. Toimintatutkimuksellisena otteen johdosta ko. ryhmä on toiminut koko tutkimusprosessin ajan. Ryhmän toiminta koostui aluksi Jyväskylän seudun ammatilliseen erityisopetukseen tutustumisesta ja keskustelujen myötä jäsennettiin yhteistoiminnallisesti erityisopettajan työtä.

Tutkimuksen tarkoituksena oli tarkastella erityisopettajan työtä osana ammatillista koulutusta. Tutkimuskohteena oli Jyväskylän ammattiopisto, jonka erityisopetuksen historiallinen analyysi kohdistui sen kehityslinjojen ja toimintamallien tarkasteluun osana ammatillisen koulutuksen muutosta. Historiallinen analyysi toimi tämän päivän erityisopetuksen ymmärtämisen taustana.

Nykytoiminnan analyysi oli tutkimuksen toinen vaihe, jonka päätehtäväksi muodostui ammatillisen erityisopettajan työn kokonaisuuden ja työorientaatioiden tarkastelu. Historiallisen sekä nykytoiminnan tarkastelun pohjalta hahmoteltiin ammattiopiston erityisopetuksen tämän päivän kehittämisen haasteet.

Tutkimuksen viitekehyksenä oli kehittävä työntutkimus, jonka mukaan uudistukset mahdollistuvat tuntemalla kohteen historiallinen tausta ja sieltä nousevat kehityshaasteet.

Kehittävä työntutkimus on 1980-luvulla Suomessa kehitetty lähestymistapa työn ja organisaatioiden tutkimiseen ja kehittämiseen (Engeström 2002, 11-12). Kehittävä työntutkimus pyrkii yhdistämään tutkimuksen, käytännön kehit- tämistyön ja koulutuksen. Se on osallistava työskentelytapa, missä työntekijät analysoivat ja muuttavat omaa työtään kuitenkin niin, että ulkoapäin ei pyritä tarjoamaan valmiita ratkaisuja.

\section{Erityisopetuksen}

välineet ja mallit

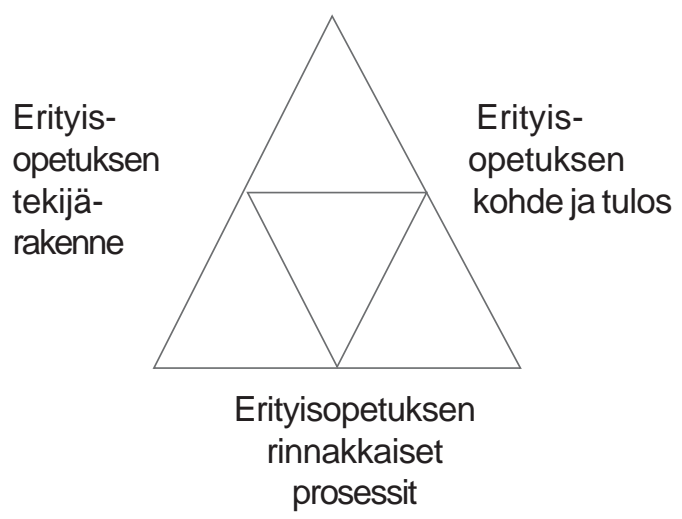

KUVIO 1. Erityisopetus työprosessina.

Kuvaamalla toimintajärjestelmää (kuvio 1) voidaan analysoida toiminnan sisäistä dynamiikkaa ja sen muutosta. Tässä tutkimuksessa erityisopetusta tarkasteltiin prosessin ja sen osatekijöiden avulla. Tutkimuksen tarkoituksena oli selvittää, mitkä ovat erityisopetuksen tekijöiden - ammatillisten erityisopettajien - asema ja tehtävät ammatillisessa koulutuksessa, mikä on heidän työnsä kohde, millaisia välineitä ja malleja he käyttävät työssään ja mitkä ovat erityisopetuksen rinnakkaisprosessit, esimerkkinä työnjakokysymykset.

Kehittävän työntutkimuksen tehtävänä on Engeströmin $(2002,126)$ mukaan tuottaa työntekijöille havaintoaineistoa työstä ja siinä esiintyvistä häiriöistä ja uutta ennakoivista ratkaisuista, asettaa heille tehtäviä työn analyysiä varten ja uuden toimintamallin muodostamiseksi sekä antaa työntekijöille käsitteellisiä välineitä näiden tehtävien suorittamiseksi. Tutkimusta voi kuvata koulutusprosessiksi, jonka tehtävänä oli tallentaa oppimisen syklin vaiheet ja analysoida niistä koottavaa aineistoa prosessin ymmärtämiseksi.

Tutkimuksen historiaosuus osoitti kaksi suurta muutostrendiä: koulutuksen kokonaismerkityksen ja oppimisympäristön muutoksen. Ammatillisen koulutuksen merkitys on muuttunut, ilman muodollista koulutusta on aiempaa vaikeampi päästä työelämään. Koulutuksen avulla 
opiskelija pyritään sitouttamaan yhteiskuntaan ja lisäämään hänen elämänhallinnan taitojaan. Koulutus ei enää ole pelkästään ammattiin kasvattamista, vaan sen tehtäviin kuuluu opiskelijan yhteiskunnallisen osallisuuden lisääminen kiinnittämällä nuori peruskoulun jälkeen toisen asteen opintoihin.

Toinen muutostrendi, oppimisympäristön kehittyminen rakenteellisesti yksinkertaisesta koulusta nykyiseen monimuotoiseen palvelukouluympäristöön aiheuttaa erityisopetukselle uudenlaisia haasteita. Oppimisympäristön monipuolisuus tarjoaa mahdollisuuksia niille, jotka sitä osaavat käyttää.

Erityisopetuksen asema on näiden kokonaismuutosten myötä muuttunut. Koko ikäluokan kouluttaminen merkitsee samalla sitä, että erityisopetuksen avulla tuetaan opintoihin kiinnittymistä niiden opiskelijoiden kohdalla, joille formaali koulutus ei ole merkittävä tai joille oman alan valinta on epäselvä. Erityisopetuksen käsite on muuttunut erityisen tuen ja ohjauksen käsitteeksi, jolloin aiemmista erityisopetuspalveluista on siirrytty monimuotoiseen (moniammatilliseen) sosiaalisen tuen ja ohjauksen antamiseen, jossa korostuvat aiemman erityispedagogisten taitojen sijasta verkostoituminen ja konsultaatio.

Edellä kuvatut muutostrendit ovat aikaansaaneet muutosvaatimuksia ammatillisen erityisopettajan työhön. Tutkimuksen nykytoiminnan anaIyysi toi esiin kaksi näkökulmaa. Erityisopettajien asema on aiemmassa palvelurakenteessa, luokkamuotoisessa erityisopetuksessa ollut selkeä. Erityisryhmillä oli selvä funktio ammatillisessa koulutuksessa, sille asetettiin selvät tavoitteet ja sitä toteuttivat vastuutetut erityisopettajat. Asiantuntijuus kehittyi pedagogisten erityistaitojen osalta. Oma ammatillinen identiteetti erityisopettajana oli vahva.

Koulutuksen rakenteen muuttuessa myös erityisopetuksen palvelurakenne muuttui. Palvelukouluympäristössä ei pelkkä luokkamuotoinen erityisopetus enää "riitä", vaan erityisopettajan työtä tulisi kehittää rakennetta vastaavaksi. Palvelukoulu luo myös erityisopetukselle uudenlaisia mahdollisuuksia, mikäli erityisopetuksen toteuttajien, erityisopettajien asema yleisissä ammatillisissa oppilaitoksissa vahvistuu. Integroidussa erityisopetuksessa erityisopettajat toimivat pääosin ammatinopettajina, erityisopetuksen näkökulmasta kaksoisroolissa. Erityisopetuksen vastuu on jakaantunut jossakin määrin kaikille opettajille, jolloin erityisopettajien työn tulisi muuttua yhteisölliseksi ja konsultatiiviseksi.

\section{Lähteet}

Ammatillisen erityisopetuksen toimenpideohjelma. Taustamuistio. Opetusministeriön monisteita 2004:1.

Engeström, Y. (2002). Kehittävä työntutkimus. Perusteita, tuloksia ja haasteita. Edita.

Klemelä, K. (1999). Ammattikunnista ammatillisiin oppilaitoksiin. Ammatillisen koulutuksen muotoutuminen Suomessa 1800-Iuvun alusta 1990-luvulle. Turun yliopisto. Koulutussosiologian tutkimuskeskuksen raportti 48

KM 1973:154. Ammatillisen erityisopetuksen toimikunnan mietintö.

Koulutuksen ja tutkimuksen kehittämissuunnitelma 2003. Opetusministeriön julkaisuja 2004:6.

Lappalainen, K. (2001). Yläasteelta eteenpäin oppilaiden erityisen tuen tarve peruskoulun päättövaiheessa ja toisen asteen koulutuksessa. Väitöskirja. Joensuun yliopiston kasvatustieteellisiä julkaisuja 71 .

Mänty, T. (2000). Ammatillisista erityisoppilaitoksista elämään. Jyväskylän yliopisto. Erityispedagogiikan laitos. Väitöskirja. Viitattu 1.3.2005.

Päivänsalo, P. \& Miettinen, K. (2003). Selvitys vammaisten opiskelijoiden valmentavasta ja kuntouttavasta opetuksesta ja ohjauksesta kevätlukukaudella 2003. Opetushallitus. Viitattu 1.3.2005.

Tilastokeskus. (2004). Erityisopetukseen otetut ja siirretyt peruskoulun oppilaat sekä osaaikaista erityisopetusta lukuvuonna 2002 saaneet peruskoulun oppilaat. Luettu 1.9.2004.

Volanen, M. V. (1997). Nuorisoasteen koulutuskokeilut koulutuksen kehittämisen ristipaineessa. Teoksessa R. Mäkinen, M. Virolainen \& P. Vuorinen (toim.) Oppilaitosten yhteistyö ja yksilölliset opinnot nuorisoasteen koulutuskokeilussa. Jyväskylän yliopisto. KTL.

Volanen, M. V. (2004). Opiskeleva Jyväskylän seutu. Toisen asteen koulutuksen alueellinen kehittäminen. Jyväskylän yliopisto. Koulutuksen tutkimuslaitoksen tutkimusselosteita 19. 